\title{
The use of Markov Chain method to determine spare transformer number and location
}

\author{
Musa Partahi Marbun ${ }^{1}$, Ngapuli Irmea Sinisuka ${ }^{2}$, Nanang Hariyanto ${ }^{3}$ \\ ${ }^{1}$ PT PLN (Persero) Head Office, System Planning Division, Indonesia \\ ${ }^{2,3}$ School of Electrical Engineering and Informatics, Bandung Institute of Technology Bandung, Indonesia
}

\begin{tabular}{l}
\hline Article Info \\
\hline Article history: \\
Received Dec 12, 2017 \\
Revised Jul 12, 2018 \\
Accepted Jul 30, 2018 \\
\hline
\end{tabular}

Keywords:

Markov chain

Probability steady state

Spare location

Spare number

Transformer

\begin{abstract}
The purpose of this study is to develop a method to determine spare transformer number and location. Using Markov Chain method, state transition model and steady state probability was used on each $500-\mathrm{kV}$ substation in order to analyze the effect of spare number and location variation with the reliability changes. To give an actual result of the case study, calculation of spare transformer number and location on $500 / 150 \mathrm{kV}$ transformers in Java Bali System was analyzed. The steady state probability results will vary depending on the number of spare transformer, these results can then be used to assess the spare transformer needed. The variation of spare transformer location can be used to analyze the best possible location of the spare in order to satisfy the reliability required. The methodology presented shows an integrated calculation for determining the spare transformer number and location.
\end{abstract}

Copyright (C) 2019 Institute of Advanced Engineering and Science. All rights reserved.

\section{Corresponding Author:}

Musa Partahi Marbun, PT PLN (Persero) Head Office, System Planning Division, Jakarta, Indonesia.

Email:musa@pln.co.id

\section{INTRODUCTION}

Normal operation of a power system ensures energy flow from generation source to load demand, through its equipment. If those equipment fails, from either or both causes in random environment, the risk of blackout is increasing. A method to reduce the risk of blackout is by providing spare equipment. The effectiveness of spare equipment is determined by its ability to maintain a certain reliability value. But, maintaining a high reliability value would increase investment cost, therefore a method to determine spare transformer parameters is needed.

Spare part is important aspect in maintaining the system reliability, several methods to determine spare part has been used, some of the method already implemented in actual electrical equipment [1], [2]. A number of research have been done specifically on spare transformer number calculation, based on these literature, most of them uses Markov Chain method [3]-[8]. However, all of the research did not consider spare location. Based on an actual condition of a power system, the output should also include spare transformer location. This paper will show the advantage of the integration of spare transformer number and location calculation.

The concept of this study is reliability calculation; the reliability definition in Markov Chain Method is a steady state probability in states which is considered as a success conditions. To obtain the above results, the calculation of reliability is calculated for each $500-\mathrm{kV}$ substation by varying the amount and location of the spare transformer. In order to give clear implementation of the method, this research uses $500 / 150 \mathrm{kV}$ transformer in Java-Bali System as the case study. 


\section{RESEARCH METHOD}

The main framework used in this research is Markov Chain Method. Based on the Markov Chain Model [9], [10], the definition of system reliability is the steady probability group of normal condition states (success states). The first step in Markov Chain Model is by making a state transition model. This research will use one spare transition state model, as shown on the Figure 1.

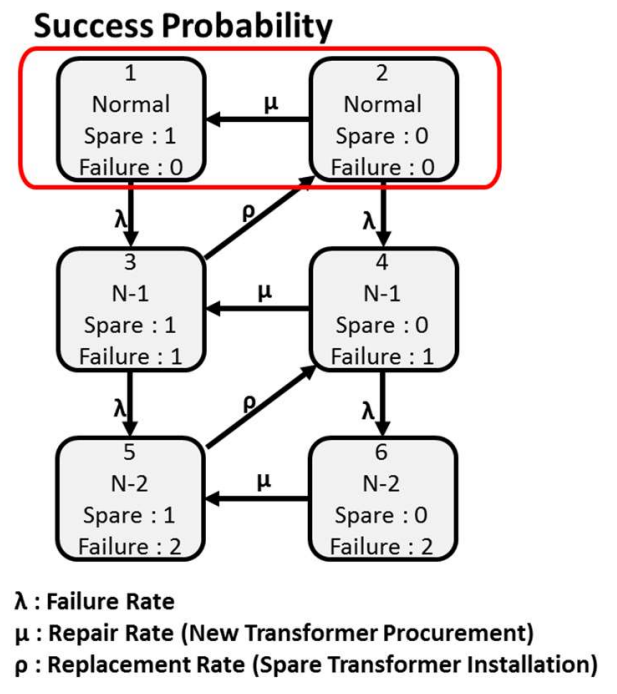

Figure 1. Transition state model of one spare transformer

Based on the Figure 1 and referring to the actual condition, the probability group of system reliability will be the steady state probability in state 1 and state 2 . while other states are defining an abnormal operation, the definition of each states are:

a. State 1 is normal condition with 1 spare available and without any system failure.

b. State 2 is normal condition with no spare available and without any system failure.

c. State 3 is N-1 condition with 1 spare available and with system failure.

d. State 4 is $\mathrm{N}-1$ condition with no spare available and with system failure.

e. State 5 is N-2 condition with 1 spare available and with 2 transformer disturbance (system failure).

f. State 6 is N-2 condition with no spare available and with 2 transformer disturbance (system failure).

Based on the Figure 1, there are three rates that will affect the calculation result which are failure rate $(\lambda)$, procurement rate $(\mu)$, and transport rate $(\rho)$. The failure rate $(\lambda)$ value is derived from A-B-C classification concept. The procurement rate $(\mu)$ is a constant value where there are no constrain in spare procurement. The transport rate $(\rho)$ is derived with spare location variation value.

The failure rate calculation uses A-B-C Classification (Pareto Law Concept) [11]. All of the assets must be classified into 'models'. The disturbance data which affected the failure rate are only those disturbances occurred on the A component based on the A-B-C classifications. For asset classification, the method used is inventory management. Inventory Management is an activity of monitoring and controlling the business and production processes of a company, from the beginning of the booking, storage, using the components, until the production process. This method has been used to classify different 'models' of any assets. The reason why these classification is necessary is because in this research, each 'model' defines the reliability in every $500-\mathrm{kV}$ substations. Each 'model' has its own failure rate, therefore to calculate this failure rate, the disturbance data needs to be classified by using Pareto Law. The Pareto principle, also known as the $80 / 20$ rule, is a theory which says that 80 percent of the output from any given situation or system is determined by 20 percent of the input.

The next step is determining the $\mu$ value and $\rho$ value. Based on an ideal repair and preventive maintenance [12], [13] concept, these values have uniform probability density based on the following formula,

$$
f_{R}=1 / T_{M}\left(e^{\frac{T_{M}}{4}-1}\right)
$$


The difference is, the $\mu$ value will be constant for every variation but the $\rho$ value will have variation value based on the spare transformer location. The one spare transition state has six possibilities of states; therefore, the calculation of the transition matrix is as shown in Figure 2.

\begin{tabular}{|c|c|cccccc|}
\hline \multicolumn{7}{|c|}{ TRANSITION MATRIX } \\
\hline \multicolumn{1}{|c|}{} & \multicolumn{7}{c|}{ TO } \\
\cline { 2 - 9 } \multicolumn{1}{|c|}{} & $\mathbf{1}$ & $\mathbf{2}$ & $\mathbf{3}$ & $\mathbf{4}$ & $\mathbf{5}$ & $\mathbf{6}$ \\
\hline \multirow{4}{*}{ FROM } & $\mathbf{1}$ & $1-\lambda$ & 0 & $\lambda$ & 0 & 0 & 0 \\
\cline { 2 - 9 } & $\mathbf{2}$ & $\mu$ & $1-\mu-\lambda$ & 0 & $\lambda$ & 0 & 0 \\
\cline { 2 - 9 } & $\mathbf{3}$ & 0 & $\rho$ & $1-\rho-\lambda$ & 0 & $\lambda$ & 0 \\
\cline { 2 - 9 } & $\mathbf{4}$ & 0 & 0 & $\mu$ & $1-\mu-\lambda$ & 0 & $\lambda$ \\
\cline { 2 - 9 } & $\mathbf{5}$ & 0 & 0 & 0 & $\rho$ & $1-\rho$ & 0 \\
\cline { 2 - 8 } & $\mathbf{6}$ & 0 & 0 & 0 & 0 & $\mu$ & $1-\mu$ \\
\hline
\end{tabular}

Figure 2. One Spare Matrix Transition

By definition, this research calculates the steady state probability. Mathematically, steady state probability is a condition where any initial state when multiplied with the transition matrix will have the same output as the initial state.

[Intial State $] \mathrm{x}[$ Transition Matrix $]=[$ Initial State $]$

Calculating the above formula by using the principle of matrix calculation will give the steady state probability results. The required output is the probability group values of all states which has normal conditions. Based on the above simple example, the output is the sum of steady state probability of state 1 and state 2 .

\section{METHODOLOGIES}

This paper will determine the spare transformer number and location by reliability of each $500-\mathrm{kV}$ substation. The main framework used is Markov Chain Model therefore the reliability is the steady state probability of Markov Chain Calculations.

\subsection{General description of the proposed model}

In order to have comprehensive effect, every $500-\mathrm{kV}$ substation have its state transition model, therefore it have its own failure rate based on the disturbance data of each substation and different transportation rate based on the location variation.

\subsection{Location variation}

The idea of transportation rate variation is based on the different range between $500-\mathrm{kV}$ substation. This assumption regarding the spare transformer, is located in the $500-\mathrm{kV}$ substation, not in a special spare warehouse. The visualization of location variation based on Table 1.

$\underline{\text { Table 1. Substation Range Table }}$

\begin{tabular}{ccccc}
\hline & & & To \\
& & A & B & C \\
\hline \multirow{3}{*}{ From } & A & 0 & 2 & 6 \\
& B & 2 & 0 & 3 \\
& C & 6 & 3 & 0 \\
\hline
\end{tabular}

In order to utilize the reliability value of each $500-\mathrm{kV}$ substation, every substation has its own Markov Chain model and its own calculation results, while every model is linked to each other by the installation rate $(\rho)$. Based on this definition, the location determination is the effect of component reliability when the installation rate $(\rho)$ changes. This installation rate value changes based on the distance changes between substations. The mathematical formula of the ideal rate [12], [13] is,

$$
f_{R}=1 / T_{M}\left(e^{\frac{T_{M}}{4}-1}\right)
$$


Therefore, the distance calculated from Table 1 will be converted into period (TM) by rough assumption of a distance per time constant factor. These assumptions were based on several actual spare transformer transportations between the substations. The installation rate will be different for every component's reliability even though each substation will have the same Markov Chain model but different installation rate and different failure rate.

\subsection{Value of lost load}

The Markov Chain calculation will produce the probability steady state of success states or reliability. Based on the results, the economical calculation should give exact number and location based on the cost/benefit analysis of spare provision. The cost component is spare price or cost, but the benefit instead of production cost or tariff, this research uses value of lost load. The first step of coming up with the benefit component is calculating the outage cost,

Outage Cost=(1-reliability) $\mathrm{x}$ capacity $\mathrm{x}$ LF $\mathrm{x}$ VoLLxtime

And the Value of Lost Load calculation is:

$$
\text { VoLL }=\frac{\text { Regional GDP }}{\text { Energy Consumption }} \times \frac{\text { Business }+ \text { Industry }}{\text { Total Consumers }}
$$

VoLL calculation assume that any electricity outages will affect the economic condition [14].

\section{RESULTS \& DISCUSSION}

$500 / 150 \mathrm{kV}$ transformer of Java Bali System was used as case study. These transformers had several conditions that needed to be classified in order to have logical calculations of spare amount number and location:

1. Classification

a. 1 phase per banks or 3 phase per bank.

b. 2 kinds of impedance.

c. Locations throughout Java

2. Failure rate calculation

Inventory management was used to classify the above conditions into several "models". These models had their own failure rates, which would be derived from Pareto Law-ABC Classifications. The next step was steady state probability calculation for every failure rates and each variation of spare location.

\subsection{Java Bali $500 / 150 \mathrm{kV}$ transformer model}

$500 / 150 \mathrm{kV}$ Transformer or Inter Bus Transformer (IBT) in Java Bali System has two types, which are the single phase per bank transformer and the 3 phase per bank transformer. The majority of the IBT in Java Bali system are single phase per banks transformer. The advantages of single phase per banks transformers are the flexibility of the spare transformer, where if there is a failure in one of the transformer, the spare will replace only one unit instead of all three. Moreover, it is lighter than 3 phase per bank transformer, where the advantage will be on transportation method aspect. The type of the transformer used for this calculation is shown in the transformer type graphical recap in Figure 3.

Looking at Figure 3, the single phase per bank transformer has two type of impedance. For this study the impedance difference will be neglected. The effect will be the loading differences, therefore in order to have good results of spare number and location, the loading differences when there is different impedance will be neglected.

The next logical way to classify the IBT was dividing substation location in Java-Bali System by its provinces. This logic is based on the transportation constrain in order to have spare location and economical calculations. There are 7 provinces in Java Bali System but only 5 provinces have the $500 \mathrm{kV}$ Substation. The IBT data by provinces is shown in Figure 4. 


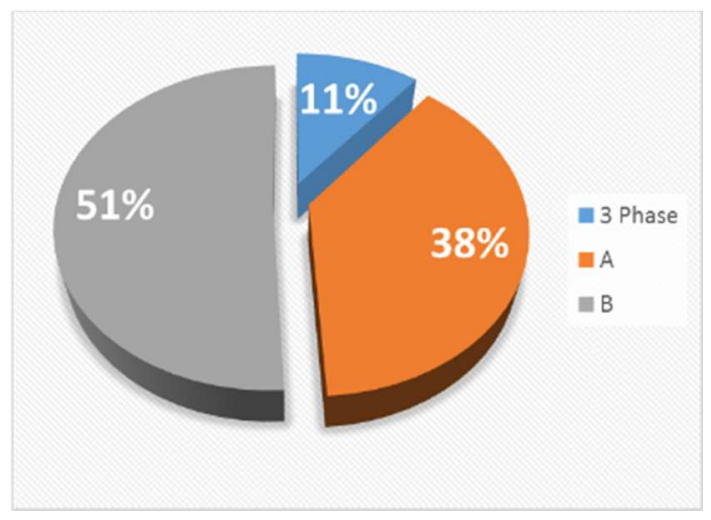

Figure 3. 500/150 kV Transformer Type

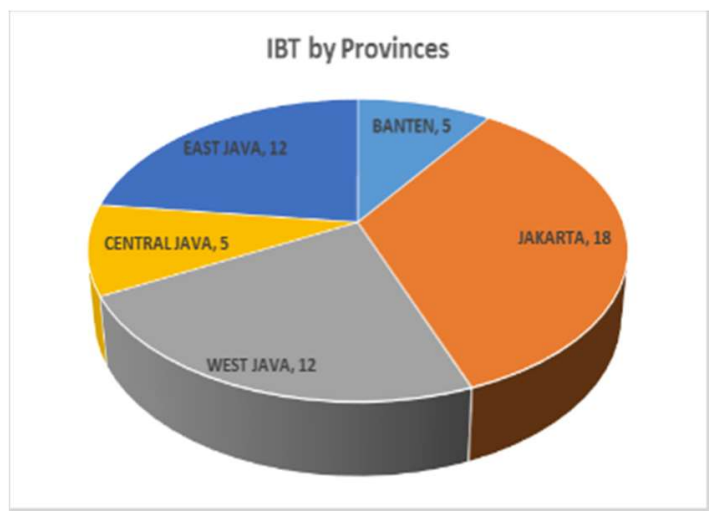

Figure 4. 500/150 kV Transformer by Provinces

Next step is determining the transformer failure classification, in order to have failure rate of each 'models'. Classification of disturbances type was recorded and compiled by maintenance engineer on Extra High Voltage Substation. The data type of this failure was taken from disturbance data from 2008 up to 2013. In order to get the failure rate, the disturbance data needs to be defined into major disturbance and minor disturbance. Pareto Law-ABC classification [11] has become a commonly used method, where the classification of A only has $20 \%$ volume of the total equipment but have the interference effect of $80 \%$. In a transformer, this principle means, the small component of a whole equipment, could disturb the whole transformer.

Based on A-B-C classification method, the transformer failure data was divided into failure/disturbance on component $\mathrm{A}$, component $\mathrm{B}$, and component $\mathrm{C}$ of the whole transformer. A-B-C classification analysis simplified the component disturbance data based on the Pareto Law where the definition of component $\mathrm{A}$ in this study is a component where its disturbance has major effect on the entire transformer and this component is unique. Component $\mathrm{B}$ is defined as components that has a high investment value but does not affect the entire transformer in maintenance or replacements phase. Component $\mathrm{C}$ is defined as supporting components. Based on the definition of the classification of A-B-C above, it can be summarized that:

1. Disturbance of component A were Bushing \& Insulators, and OLTC, by $19 \%$.

2. Interference Protection System of Component B by $31 \%$.

3. Impaired Support Tools of Component $C$ which, Outer Party, and system conditions, by $49 \%$.

Due to data limitations and monitoring equipment, Figure 5 is showing the different classification types of disturbance per IBT $500 / 150 \mathrm{kV}$ components in Java-Bali system for major disturbance. According to Pareto Law-A-B-C Classification, the Component A failure will have major effect to the entire transformer and also to the entire power system. Based on the classification of location and impedance, the failure rate from the disturbance data has been simplified into its average number. The failure rate calculation was using three units of transformer as one. This condition occurred because Java Bali System uses 1 phase per bank transformer, therefore one disturbance in one unit will fail all of the three units.

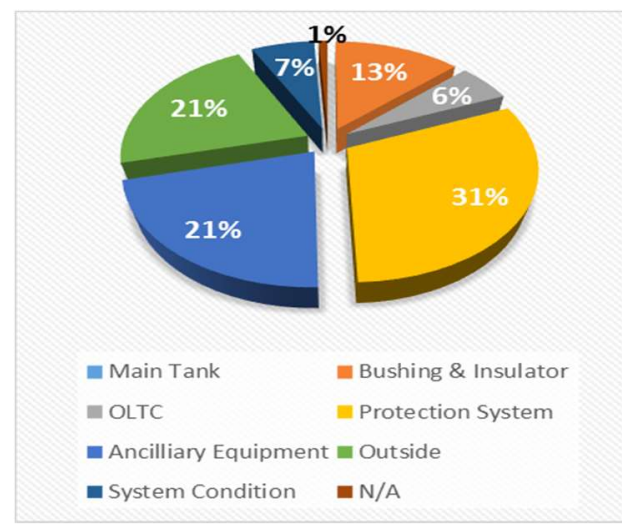

\begin{tabular}{|l|c|}
\hline \multicolumn{1}{|c|}{ Component Name } & A-B-C Classifications \\
\hline Bucholz Relay & C \\
\hline Bushing & A \\
\hline Power Supply & C \\
\hline Current Transformer & B \\
\hline Insulator & A \\
\hline Power Cable & C \\
\hline Trip Control & C \\
\hline Marshailling Kiosk & C \\
\hline OLTC & A \\
\hline CB & B \\
\hline Protection System & C \\
\hline Reactor & B \\
\hline Switch & C \\
\hline Wiring & C \\
\hline
\end{tabular}

Figure 5. Component Disturbance \& A-B-C Classifications 


\subsection{Failure rate}

Based on Section III, the first step is detailing the failure rate $(\lambda)$ into every $500-\mathrm{kV}$ substation. The results are shown in Figure 6 The results of the above figures were using statistical data for every IBT in Java Bali System. The calculation of failure rates of each substation was based on A-B-C classification.

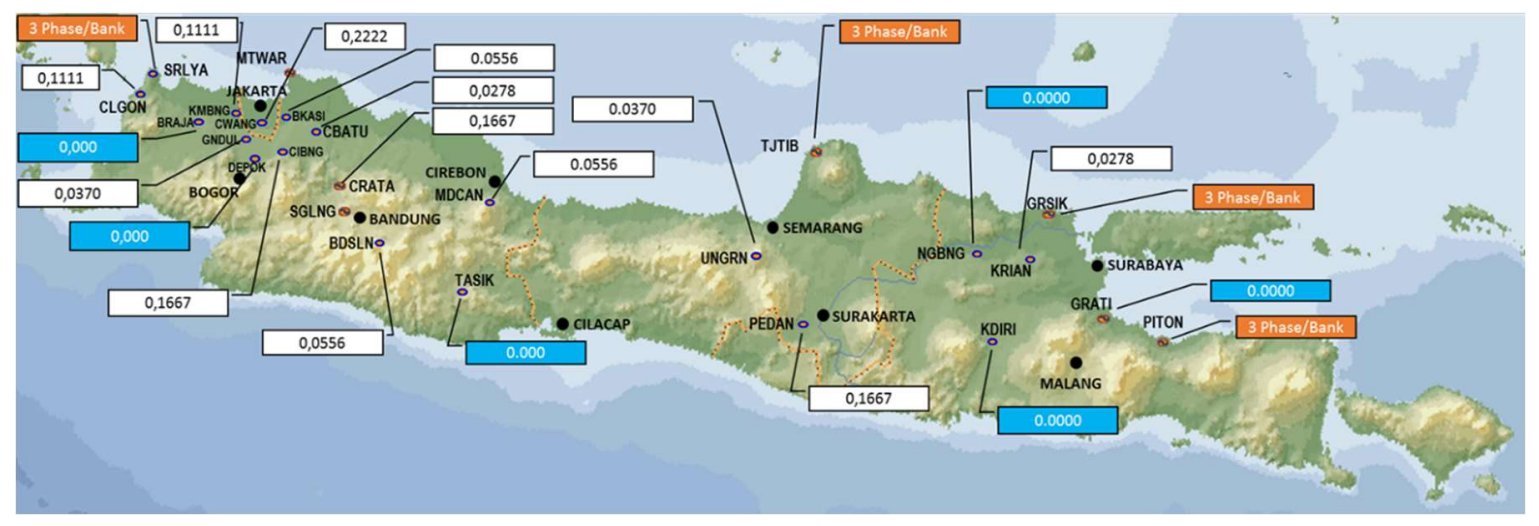

Figure 6. $500 \mathrm{kV}$ Substation failure rate

\subsection{Transportation rate}

The next step is modeling the range data between $500 \mathrm{kV}$ substations, the transportation model is shown in the Table 2 Based on the above data assumption, there will be a significant installation rate value. The one-spare Markov Chain model on each substation is linked to each other by the installation rate value.

Table 2. Range Between Each 500-kV Substation

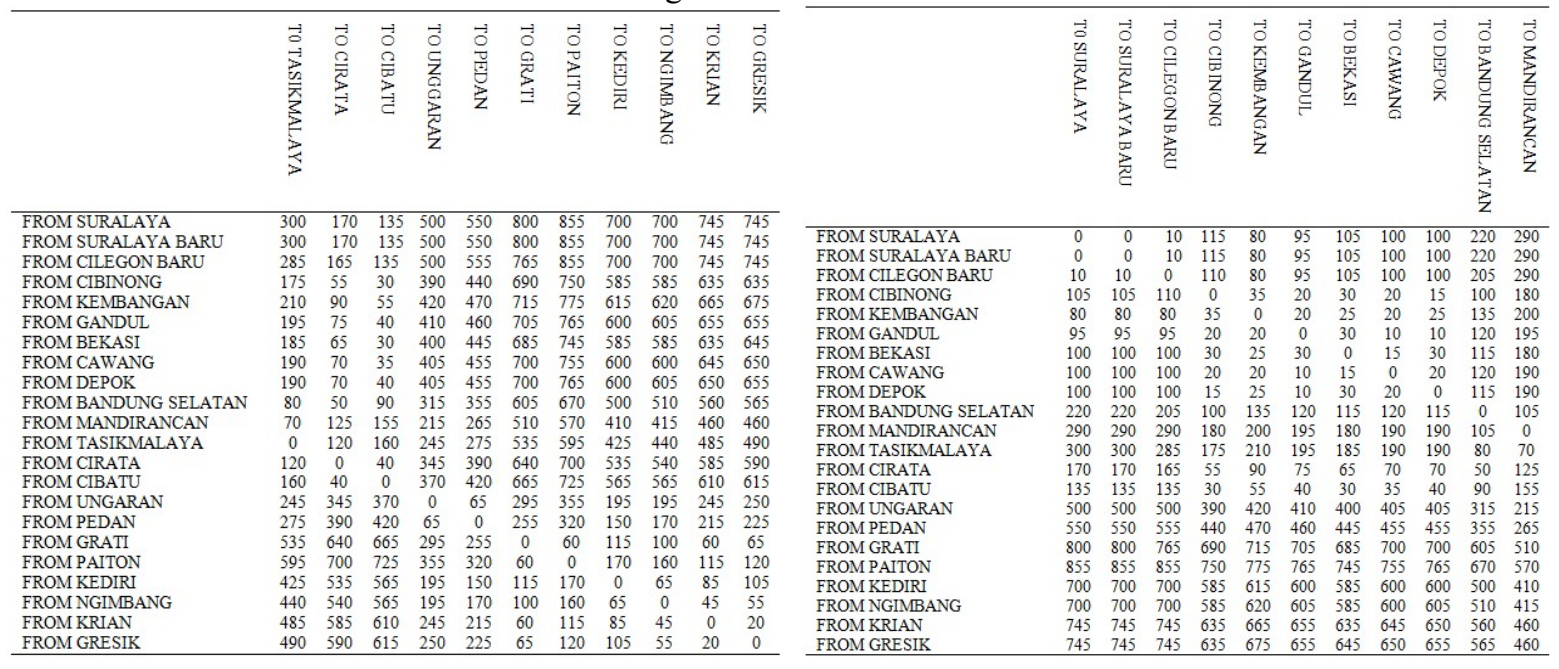

\subsection{Spare number and location results}

The steps are putting the spare transformer at Cilegon Substation, by using the data in Table 2. The installation rate on Markov Chain model at Cilegon Substation, and another different substation. Thus, the steady state probability group at each Substation will be different. The second scenario and so on is done by changing the spare transformer location. The location optimization is the steady state probability group calculation result that changes as the installation rate changes as well. The results calculation of probability steady state of each $500-\mathrm{kV}$ substation with spare IBT location variation is shown in Table 3 .

Based on the results above, each provinces should have a spare, because the significant increase of reliability occur from 0 spare to 1 spare. Based on the reliability calculation, the spare number should be 5 ( 1 in every province) and the optimum locations are Cilegon, Gandul, Cibatu, Ungaran, and Krian (Green color). The next calculation is by comparing these with the economic criteria. 
Table 3. Calculation Results

\begin{tabular}{|c|c|c|c|c|c|}
\hline GITET & O Spare & 1 Spare & 2 Spare & 3 Spare & 4 Spare \\
\hline Suralaya & - & - & - & - & - \\
\hline Suralaya Baru & - & - & - & - & - \\
\hline Cilegon & 0.4718932 & 0.9493701 & 0.9620499 & 0.9633226 & 0.9634550 \\
\hline Balaraja & - & - & - & - & - \\
\hline Kembangan & 0.7015161 & 0.9706113 & 0.9776816 & 0.9776816 & 0.9776816 \\
\hline Cawang & 0.2235391 & 0.8532107 & 0.8532107 & 0.8532107 & 0.8532107 \\
\hline Gandul & 0.7962396 & 0.9860126 & 0.9860126 & 0.9860126 & 0.9860126 \\
\hline Depok & - & - & - & - & - \\
\hline Bekasi & 0.7015161 & 0.9670808 & 0.9688456 & 0.9776816 & 0.9776816 \\
\hline Cibinong & 0.3203320 & 0.8883486 & 0.8883486 & 0.8883486 & 0.9107184 \\
\hline Cibatu & 0.8461596 & 0.9898468 & 0.9898468 & 0.9898468 & 0.9898468 \\
\hline Cirata & 0.3203320 & 0.8663371 & 0.8663371 & 0.8663371 & 0.9107184 \\
\hline Bandung Selatan & 0.7015161 & 0.9459764 & 0.9776816 & 0.9776816 & 0.9776816 \\
\hline Mandirancan & 0.7015161 & 0.9233003 & 0.9407244 & 0.9776816 & 0.9776816 \\
\hline Tasikmalaya & - & - & - & - & - \\
\hline Pedan & 0.3203320 & 0.8393674 & 0.9107184 & 0.9107184 & 0.9405737 \\
\hline Ungaran & 0.7962396 & 0.9860126 & 0.9860126 & 0.9877685 & 0.9877685 \\
\hline Tanjung Jati & - & - & - & - & - \\
\hline Kediri & - & - & - & - & - \\
\hline Ngimbang & - & - & - & - & - \\
\hline Krian & 0.8461596 & 0.9899606 & 0.9908443 & 0.9908670 & 0.9908676 \\
\hline Grati & - & - & - & - & - \\
\hline Gresik & - & - & - & - & - \\
\hline Paiton & - & - & - & - & - \\
\hline
\end{tabular}

\subsection{Spare number and location by economical criteria}

The economic criteria are comparing the cost and benefit. The cost component is spare transformer price, with the assumption of Rp 3.24 B (around 240.000,- USD) The benefit component is the outage cost with value of lost load, whereas the value of lost load in each province is shown in Table 4. Based on the above calculation results and the calculation result of spare cost, the outage cost with spare number and location variation are calculated and analyzed. The results for 500-kV Substation in Banten in Figure 7.

Table 4. Value of Lost Load

\begin{tabular}{clc}
\hline Provinces & \multicolumn{2}{c}{ Value of Lost Load } \\
\hline Banten & $\operatorname{Rp~4,247}$ & $/ \mathrm{kwh}$ \\
Jakarta & $\operatorname{Rp~8,888}$ & $/ \mathrm{kwh}$ \\
West Java & $\operatorname{Rp~4,906}$ & $/ \mathrm{kwh}$ \\
Central Java & $\operatorname{Rp~4,481}$ & $/ \mathrm{kwh}$ \\
East Java & $\operatorname{Rp~7,300}$ & $/ \mathrm{kwh}$ \\
\hline
\end{tabular}

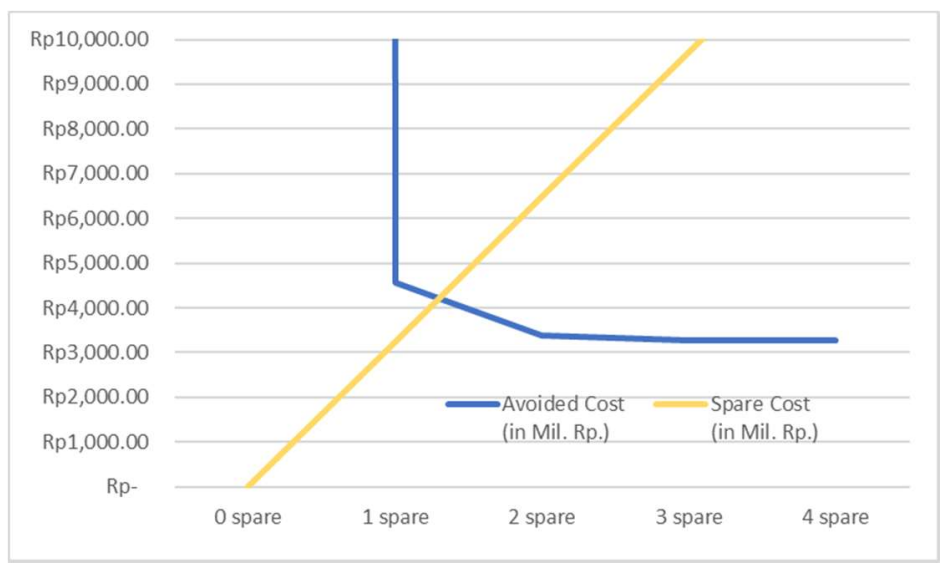

Figure 7. Cilegon 500-kV substation results

Based on the above results, the spare number is 1 referring to the crosspath between spare cost and avoided cost, and spare location in Cilegon Substation (no other $500 \mathrm{kV}$ substation). The next results for 500-kV Substation in DKI Jakarta in Figures 8-12. 


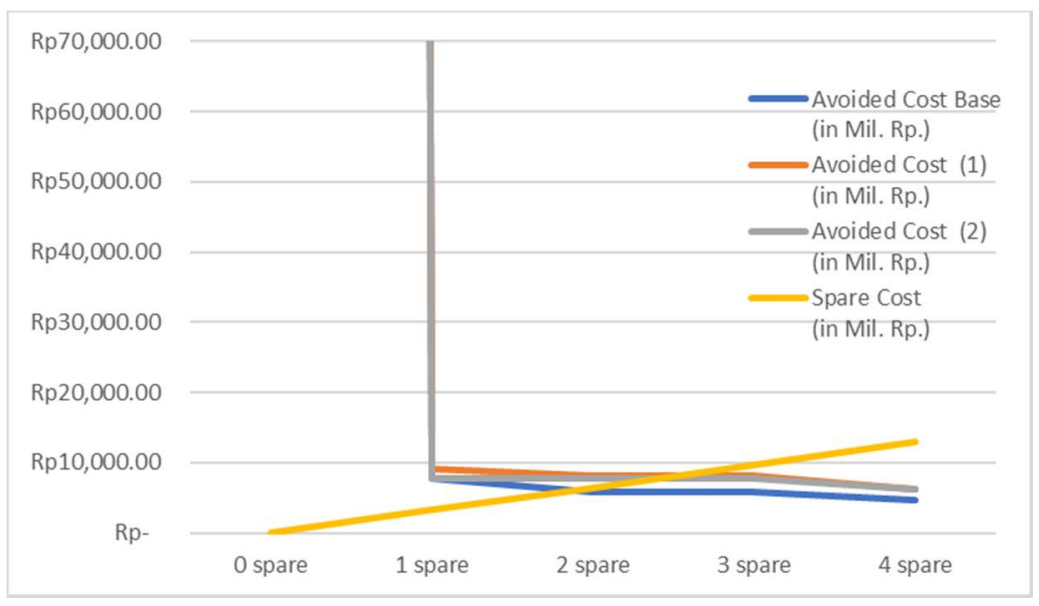

Figure 8. Kembangan 500-kV substation results

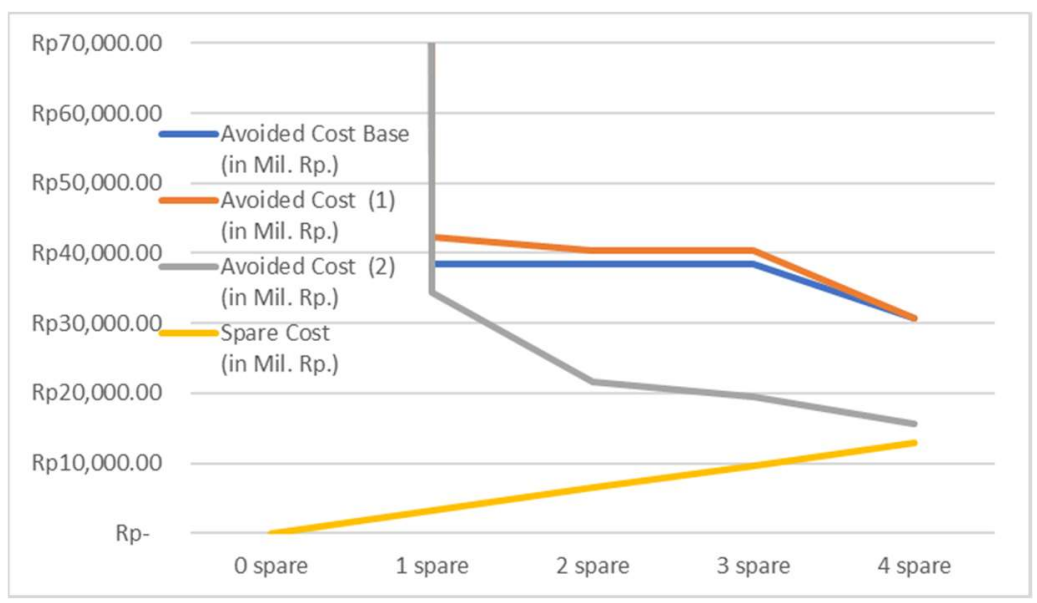

Figure 9. Cawang 500-kV substation results

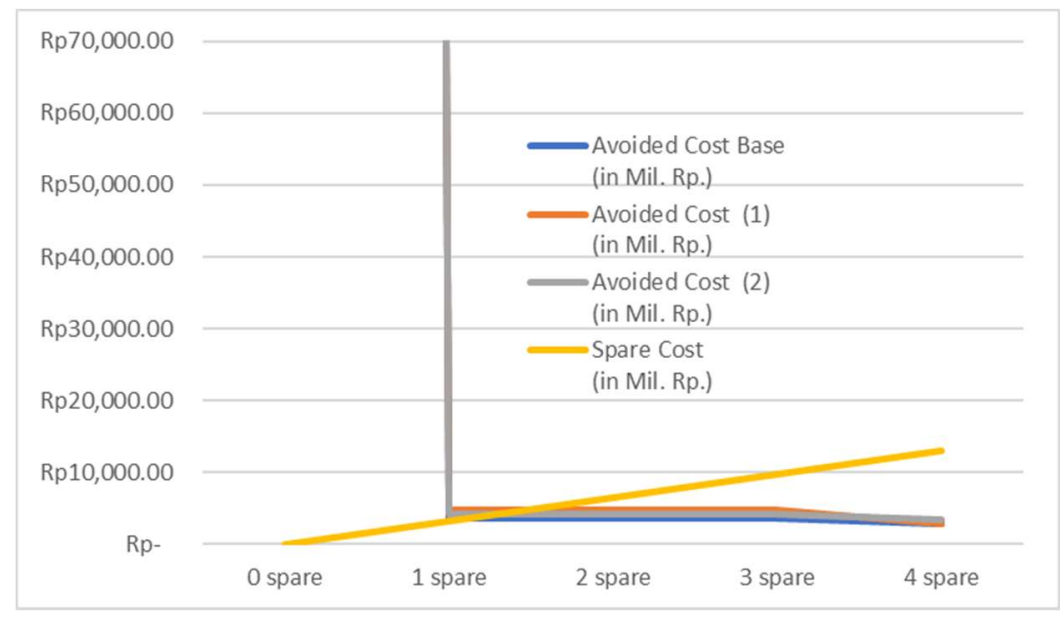

Figure 10. Gandul 500-kV substation results 


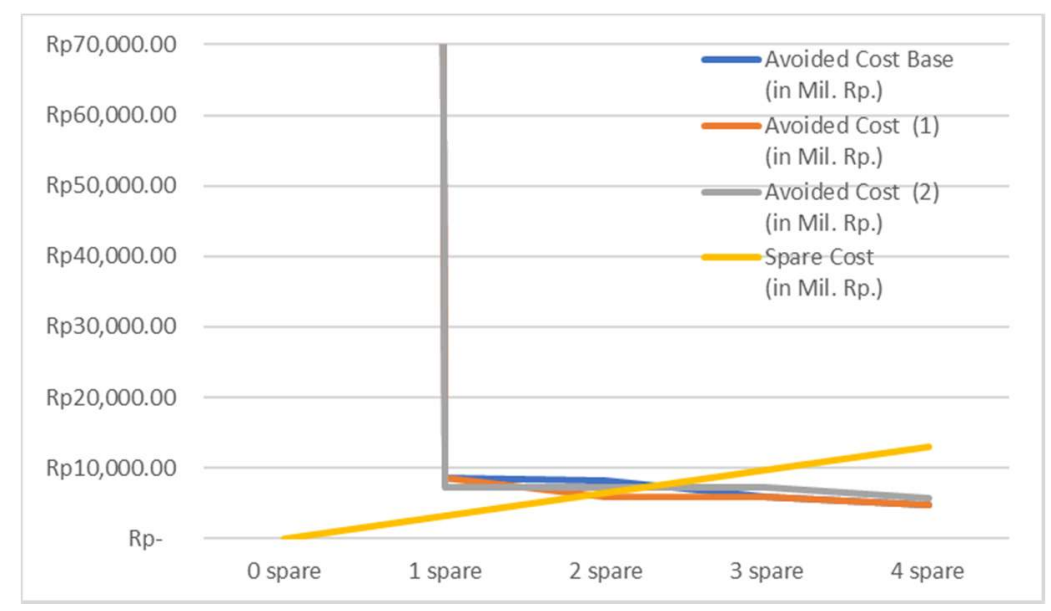

Figure 11. Bekasi 500-kV substation results

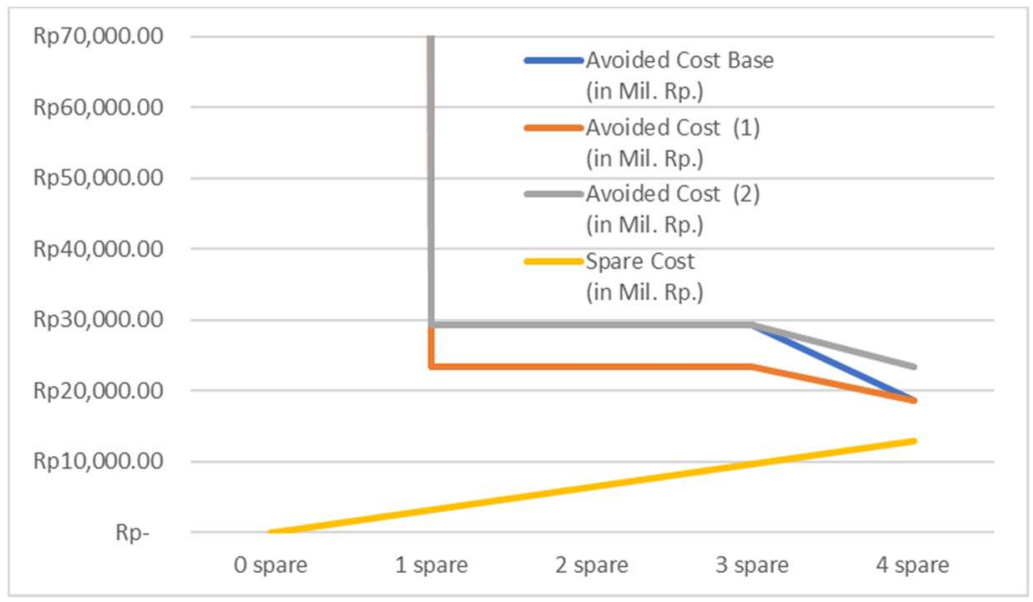

Figure 12. Cibinong 500-kV substation results

Based on the above results, the spare number is 2 (corresponding to the Kembangan and Bekasi results) and the location of each spare is in Cawang and Cibinong (corresponding to the small effect of Bekasi and Gandul reliability on spare location variation). The Cawang and Cibinong must have a follow up on reducing the disturbance, because its problem cannot be solved with spare provision. The next results for 500-kV Substation in West Java in Figures 13-16.

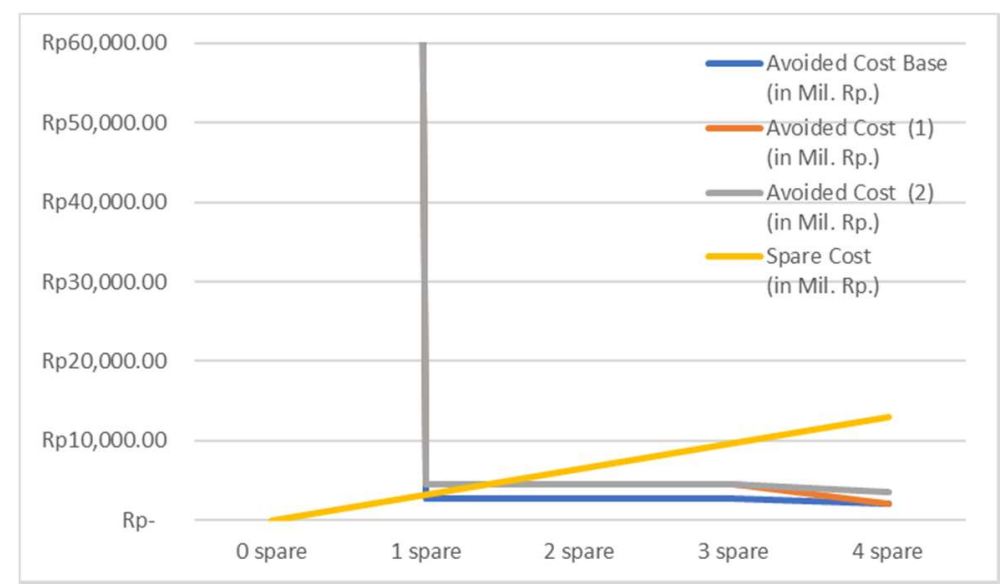

Figure 13. Cibatu 500-kV substation results 


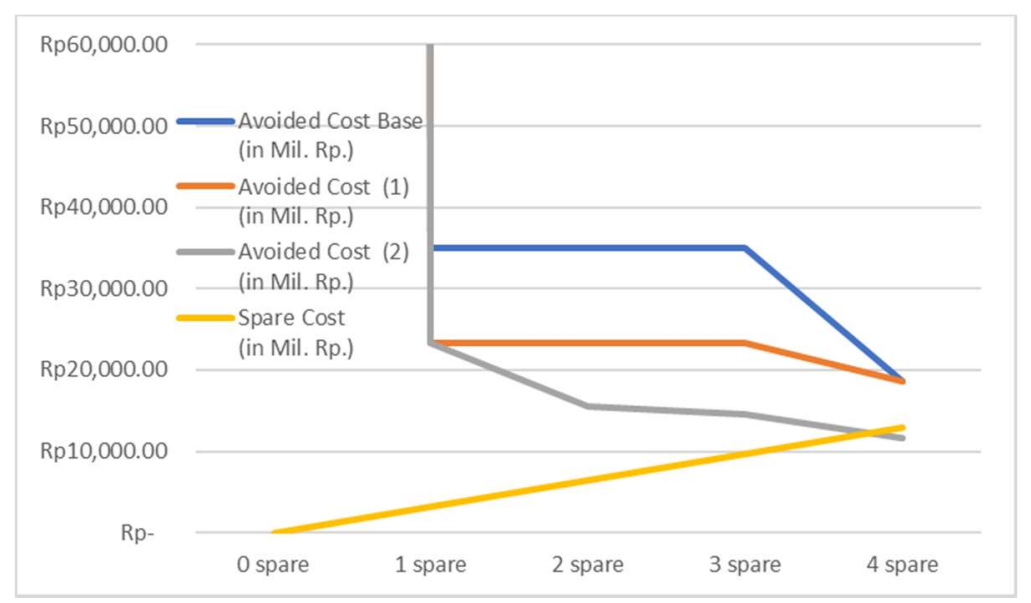

Figure 14. Cirata 500-kV substation results

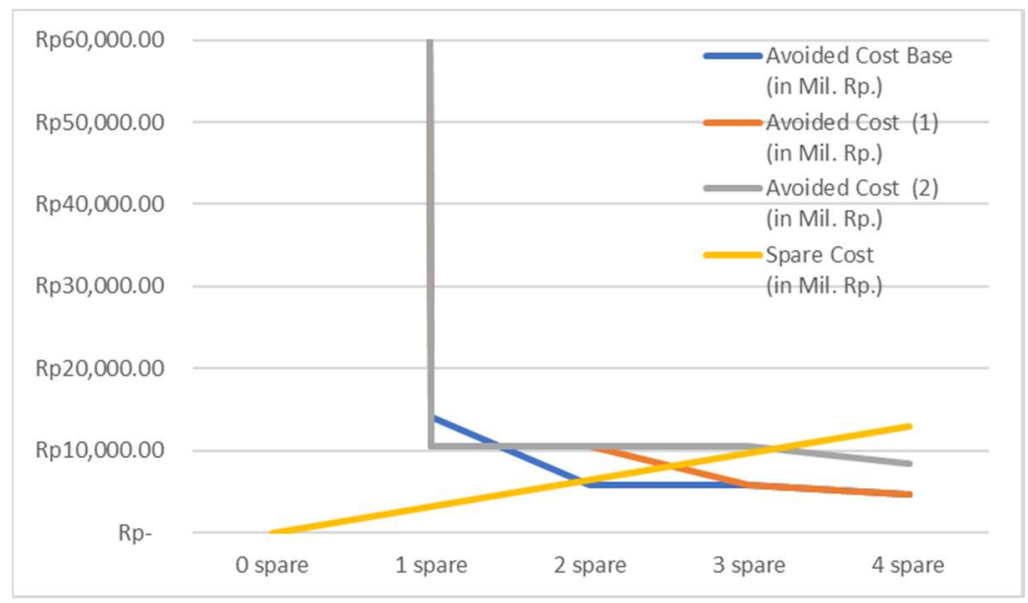

Figure 15. Bandung Selatan 500-kV substation results

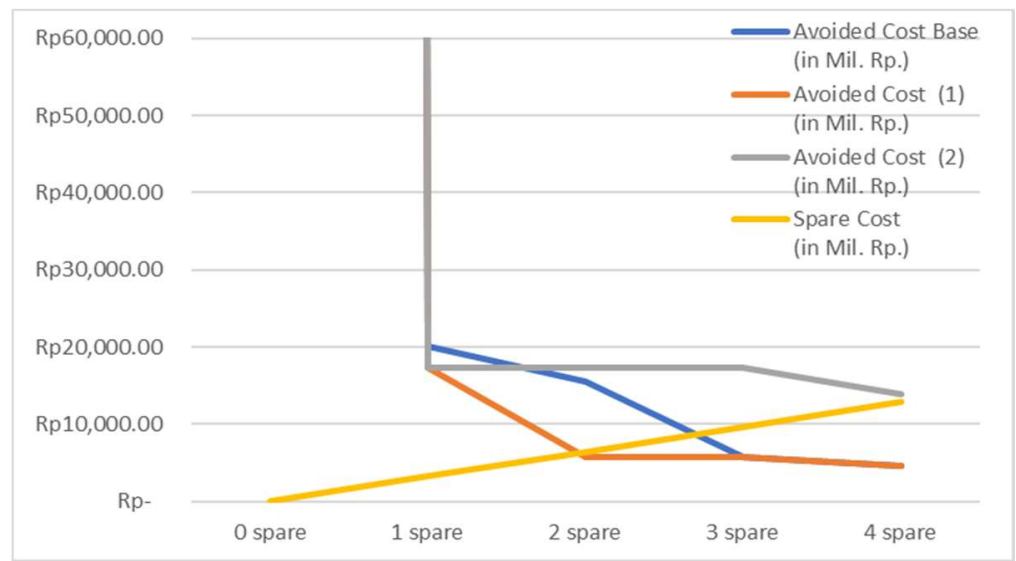

Figure 16. Mandirancan 500-kV substation results

Based on the above results, the spare number is 2 (corresponding to the Mandirancan results) and the location of each is in Mandirancan (corresponding to location variation 1), and Cirata (corresponding to the small effect of Cibatu reliability on spare location variation). The Cirata must have a follow up on 
reducing the disturbance, because its problem cannot be solved with spare provision. The next results for 500-kV Substation in Central Java in Figures 17-18.

Based on the above results, the spare number is 2 and the location of each is in Ungaran and Pedan. Based on the Pedan results, both spares should be located in Pedan, but the effect on Ungaran will be greater if the location of each is in Pedan and Ungaran. The 3 spares provision will be too high and redundant. The next results for East Java in Figure 19.

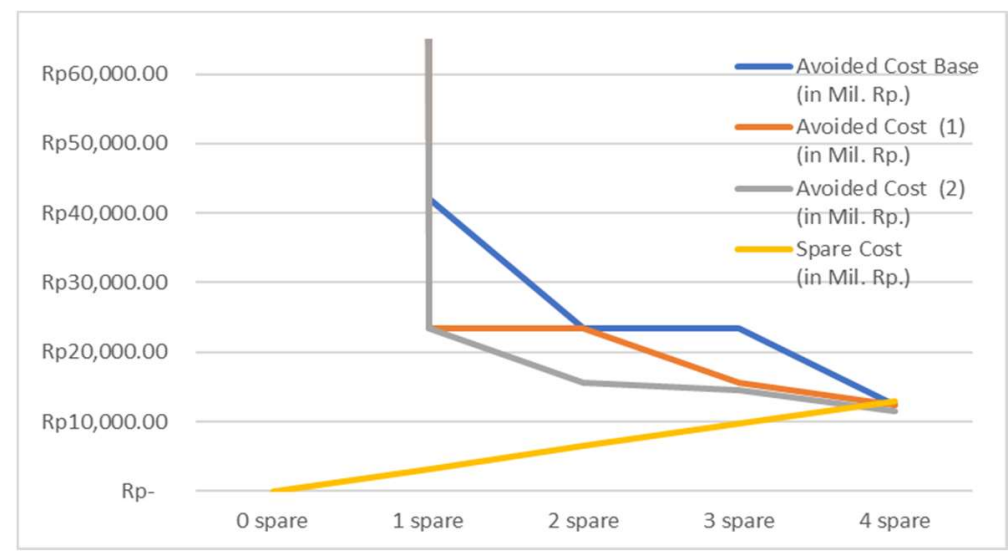

Figure 17. Pedan 500-kV substation results

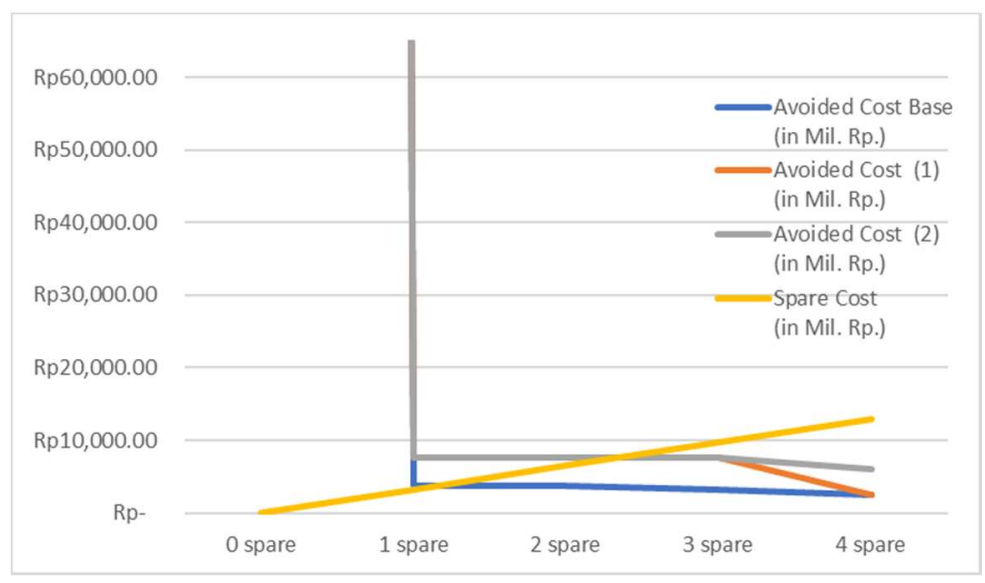

Figure 18. Ungaran 500-kV substation results

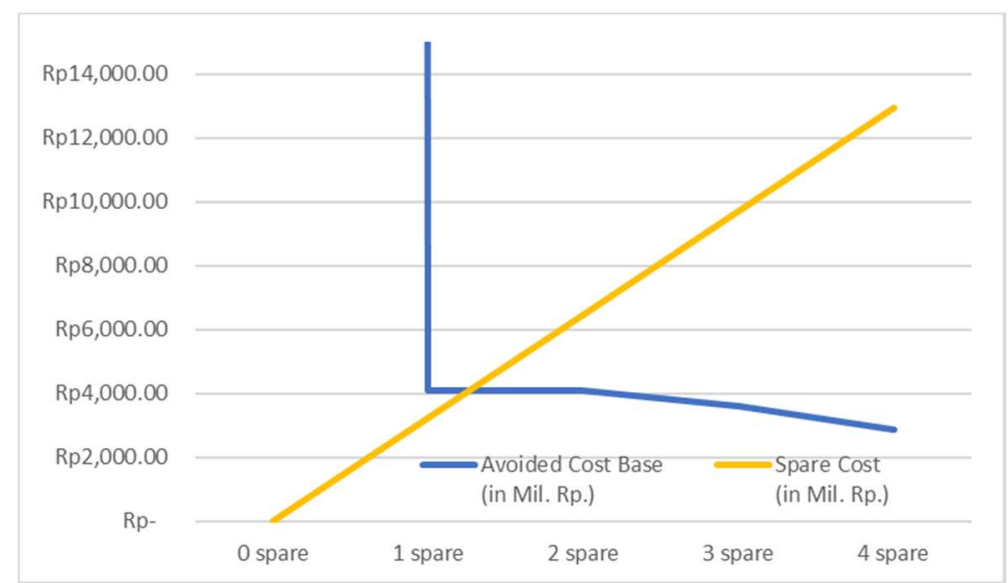

Figure 19. Krian 500-kV substation results 


\subsection{Discussion}

These results give two major revelation regarding transformer spare, especially in Java-Bali system. First revelation is optimal number of spare transformer number, the idea of increasing spare transformer number will not increase significant reliability, and there are certain limit of spare transformer number. Therefore, some investment cost could be saved if the spare transformer number is limited. Second revelation is the effect of location variation to maintain reliability of each substation show that with the optimum way of putting the spare transformer could maintain reliability of overall system reliability, these aspects currently overlooked by other research.

\section{CONCLUSION}

Markov chain gives the best calculation to determine the number and location of spare transformer by varying every possible combination. Markov Chain model in every $500 \mathrm{kV}$ substations gives clear reliability results based on the variation above. Most of the current studies have not clearly consider the spare location output, on the other hand this research finds the opportunity to maintain the system reliability by changing the installation rate. This installation rate defines the location of spare transformer. Based on the calculation results, there are significant effect on system reliability if the spare number and location could be determined by this method. Economic criteria give better determination of spare number and location, instead of reliability measure standalone as the criteria.

\section{REFERENCES}

[1] Gao Jj, Jiang Lq, Guo Q, Han Jc, Zhao Rf, Wang C., "Spare Parts Support Optimization Algorithm Based on Support Degree", TELKOMNIKA Indonesian Journal of Electrical Engineering, 11(8); 4393-4398, 2013.

[2] Song Z, Fu Z, Wang H, Hou G., "Demand Forecasting Model of Port Critical Spare Parts", TELKOMNIKA Indonesian Journal of Electrical Engineering, 12(5); 3483-3490, 2014.

[3] Chowdhury AA, Koval DO., "Development of Probabilistic Models for Computing Optimal Distribution Substation Spare Transformers", IEEE Transaction on Industry Applications", 41(6); 1493-1498, November 2005.

[4] Leite da Silva AM, Costa JGC, Chowdhury AA., "Probabilistic Methodologies for Determining the Optimal Number of Substation Spare Transformers", IEEE Transaction on Power System, 25(1); 68-77, February 2010.

[5] Hamoud GA., "Assessment of Spare Transformer Requirements for Distribution Stations”, IEEE Transaction on Power System, 26(1); 174-180, February 2011.

[6] Hamoud GA., "Use Of Markov Models in Assesing Spare Transformer for Distribution Stations", IEEE Transactions on Power Systems, 27(2), May 2012.

[7] Marbun MP, Sinisuka NI. Hariyanto N., "Inventory Management Method to Determined Spare transformer", IEEE TENCON. Macao, 2015.

[8] Marbun MP, Sinisuka NI, Hariyanto N. "The Use of Markov Chain Method to Determine Spare Transformer Number with 3-Parameters", IEEE PMAPS, Beijing, 2016.

[9] Billinton R, Allan RN. "Reliability Evaluation of Engineering Systems", 2nd ed. New York, NY, USA: Plenum, $1983,1992$.

[10] Anders GJ., "Probability Concepts in Electric Power Systems", New York, NY, USA: Wiley, 1990.

[11] Suwanasri T, Srisongkram W, Suwanasri C. "Inventory Management of Power Circuit Breaker Using Failure Data Analysis", IEEE PMAPS. Durham, 2014.

[12] Endrenyi J. "Reliability Modeling in Electric Power Systems", John Wiley \& Sons, 1978.

[13] Papoulis A. "Probability, Random Variables and Stochastic Process", $3^{\text {rd }}$ ed. New York, USA: McGraw-Hill, 1965 and 1991

[14] Pratiknjo A. "The Price of Supply Security of Electricity Energy against Terrorism", Proceeding of $10^{\text {th }}$ IAEE European Conference, Vienna. 2009.

\section{BIOGRAPHIES OF AUTHORS}

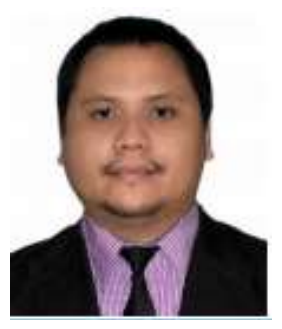

Musa Partahi Marbun was born in Jakarta, Indonesia, in 1985. He received his Electrical Engineering degree, Electrical Master degree, Doctoral in School of Electrical Engineering and Informatics from Bandung Institute of Technology, Indonesia, in 2009, 2011, and 2017 respectively. He is currently working for the State-Owned Electric Utility Company in Indonesia (PT PLN (Persero)). His research interests include probability method applied on power system. 


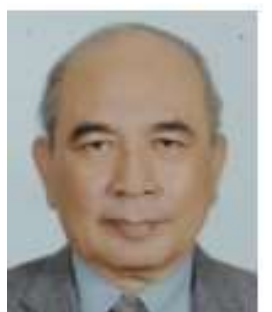

Ngapuli I Sinisuka was born in Medan, Indonesia, in 1950. He received his Electrical Engineering degree from Bandung Institute of Technology, Indonesia, and Dr-Ing from Université Paul Sabatier, Toulouse, France, in 1974 and 1980, respectively. Currently he is a Full Professor at the School of Electrical Engineering and Informatics Bandung Institute of Technology, Indonesia. His research interests include electrical insulation, maintenance engineering, economic of electric energy systems, as well as statistics and optimization theory and its applications and risk analysis.

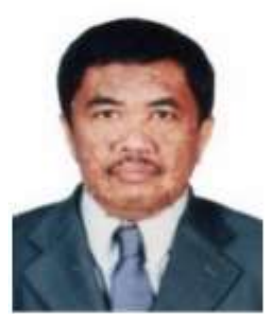

Nanang Hariyanto was received the doctor degree in 2010 in electrical engineering from Institut Teknologi Bandung. He is currently working as a head of electric power system laboratory and a head of electrical power engineering study program of School of Electrical Engineering \& Informatics ITB. His main research interest includes power system stability, power system control and power system operation, and power system reliability and economics 